
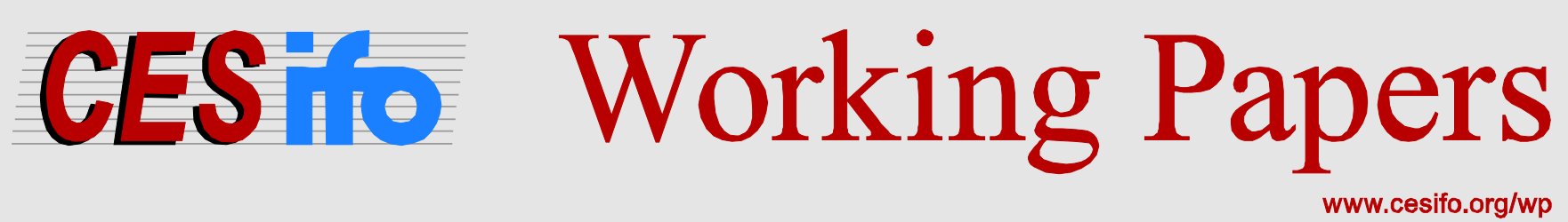

\title{
Labour Market Participation in Brazil: A Discrete Game Approach
}

\author{
Marcelo Resende \\ Vicente Cardoso
}

\section{CESIFO WORKING PAPER NO. 6337}

CATEGORY 4: LABOUR MARKETS

FEBRUARY 2017

An electronic version of the paper may be downloaded
- from the SSRN website: $\quad$ www.SSRN.com
- from the RePEc website:
- from the CESifo website: $\quad$ www.RePEc.org 


\title{
Labour Market Participation in Brazil: A Discrete Game Approach
}

\begin{abstract}
The paper aims to investigate the labour market participation of couples in Brazil in 2013. The observed endogenous variables portraying participation are assumed to be the outcome of a static discrete game between the partners. Different solution concepts are considered (Nash, Stackelberg and imposed Pareto optimality), and the estimations are implemented for rural and urban areas. The evidence, in comparison with previous evidence for more developed and homogeneous countries, displays qualitative similarities in terms of own wage, cross wage and age effects and a stronger inhibiting role of the number of small children in the case of the female partner. In particular, cross-wage effects also indicated gender asymmetry. Additionally, one identifies a more limited role of schooling on labour market participation in rural areas and gender contrasts in terms of the number of persons in the household that have a positive significant effect only for male partners.
\end{abstract}

JEL-Codes: J210.

Keywords: labour market participation, discrete game, Brazil.

\author{
Marcelo Resende \\ Instituto de Economia \\ Universidade Federal do Rio de Janeiro \\ Av. Pasteur 250, Urca, 22290-240 \\ Rio de Janeiro-RJ, Brazil \\ mresende@ie.ufrj.br
}

\author{
Vicente Cardoso \\ Banco Nacional de Desenvolvimento \\ Econômico e Social-BNDES \\ Av. República do Chile 100, 20031-917 \\ Rio de Janeiro-RJ, Brazil \\ vicentescardoso@bndes.gov.br
}




\section{Introduction}

The study of decisions within a household still motivates a non-trivial discussion on the proper approach to assess such decision units. Becker (1964) pioneered the application of consumer theory to the family. At the empirical frontier, one often relies on more aggregate data from surveys that may not favour intra-household analyses and are consistent with a more aggregate perspective. Nevertheless, the controversy between unitary and non-unitary models of household behaviour is by no means settled, as suggested, for example, by McElroy (1990), Chiappori and Donni (2011) and Grossbard (2011). In fact, the relevant literature on household behaviour clearly distinguishes between the cooperative and non-cooperative approaches. In the former, the allocations in the household reflect collective decisions and are assumed to be Pareto efficient, whereas in the latter category, one considers a non-cooperative game-theoretic approach with the related solution concepts, as for example the Nash equilibrium. A key issue is to what extent the preferences of the household members are unalike.

Potential heterogeneities across members of a household might be related to contrasts that can be traced back to essential gender differences, whether more structural or cultural. Empirical challenges to the unitary perspective on household behaviour are evident. Thomas (1990) considered survey data on family health and nutrition in Brazil, and the evidence did not provide support for the common preference model of the household, as parental income effects on child survival probabilities were not homogeneous across parents. 
More generally, gender differences can be potentially relevant particularly when one is focusing on labour force participation, which is the object of the present paper. Even if gender segregation in terms of wage differentials does not appear to be decisive in curbing female labour force participation, as suggested by Barros et al. (1995), it is possible to conceive asymmetries within the household that might make the aforementioned unitary models of the household questionable.

The resort to empirical models for discrete games provides a possible methodological alternative for assessing heterogeneous preferences within households. Bjorn and Vuong $(1984,1985)$ assume that actually observed choices are consistent with particular equilibrium concepts and outline identification and estimation approaches using Nash and Stackelberg models in the context of labour force participation. ${ }^{1}$ The illustrative empirical application that follows is further enhanced by Kooreman (1994), who also considered a Pareto efficient model applied to Dutch survey data for couples. Thus, one can highlight noncooperative models that may or may not allow for leadership behaviour of one of the partners and yet impose Pareto optimality and are compatible with a collective decision in the household. The empirical evidence has made use of models with a relatively limited number of controls for individual characteristics but indicated some noticeable results, such as the asymmetric effect of one spouse's wage on the participation of the other member of the couple. ${ }^{2}$

\footnotetext{
${ }^{1}$ Kooreman and Kapteyn (1990) discuss identification issues in terms of game-theoretic models for labour supply with an empirical illustration that benefits from information on preferred working hours.

${ }_{2}^{2}$ Nevertheless, the game-theoretic approach to labour force participation includes only a handful of contributions, and another example pertains to volunteer work participation as exemplified by Abbott (2009).
} 
Previous empirical evidence on labour force participation in Brazil appears to favour the existence of heterogeneous preferences within households. The evidence based on the same survey data for Brazil [Pesquisa Nacional por Amostra de Domicílios (PNAD-IBGE)] is suggestive. Sedlacek and Santos (1991), based on survey data for the 1980s, also highlight a negative income effect associated with the husband's work and therefore suggest a non-negligible dependence of the wife on her husband. Hoffmann and Leone (2004) investigated labour force participation and household inequality in the period of 1981-2002. The decomposition of the Gini index by factor components displayed a decrease in the participation of men's earnings and an increase in the participation of both women's earnings and pensions in the inequality of per capita household income. Thus, gender differences, while relevant, might also show important changes over time. Finally, Ramos et al. (2011) address the role of the socio-economic status of the household in women's participation in the labour force, taking as a reference survey data for the period of 2001-08. Participation was found to be stronger among poorer households and weaker when the number of preschool children was larger.

Altogether, the previous evidence suggests potentially relevant gender differences in the context of labour force participation and the need for careful controls for heterogeneity across households. Moreover, even though it is possible that some of those differences have faded over the years, the issue still is relevant. The present paper undertakes a discrete game-theoretic application to labour force participation in the Brazilian economy. It intends to contribute in at least two levels: 
a) Previous game-theoretic applications that are analogous to the present study were based on smaller and more homogeneous economies. The consideration of a large and heterogeneous developing economy similar to Brazil may potentially uncover important gender differences that are relevant for labour force participation. Thus, the empirical application for such a complex economy, segmented by rural and urban areas, might potentially underscore differences between more traditional and more modern regions;

b) Potential shortcomings of earlier related evidence included the reliance on a relatively limited number of controls given estimation problems and a strongly asymmetric criterion for defining women's labour force participation, as any part-time effort was accepted. The present paper also attempts to improve on those aspects.

The paper is organized as follows. The second section provides a brief overview on the specification of non-cooperative and cooperative discrete models for labour force participation. The third section discusses the data construction and the specification of the different empirical models. The fourth section presents and discusses the estimated results. The fifth section provides some final comments and suggests avenues for possible future research.

\section{Discrete Games of Labour Market Participation: an Overview}

\section{1- Introduction}

The random utility model discussed in McFadden (1981) provides an economic foundation for discrete choice models where the observed value for a discrete 
endogenous variable can be related to particular values of latent variables reflecting differences between unobserved utilities associated with the occurrence and nonoccurrence of a particular action. The model contends that the total utility associated to a particular choice may be decomposed in terms of the sum of a deterministic component that can be related to particular observed exogenous variables and a stochastic term. An immediate challenge concerns the extension of the single agent choice formulation to a multiple agent choice model with various interdependencies. In principle, one could conceive a simultaneous probit model as a useful generalization of the single agent problem; however, as indicated by Heckman (1978), the required coherency restrictions on the parameters eliminate the proposed simultaneity. Bjorn and Vuong (1984) further elaborate on that issue in the context of labour market participation. In particular, the authors address the referred shortcoming by considering two simplifying assumptions. First, the difference in the stochastic components between working versus not working is equal across the choices of the partner and the implied stochastic components for the male and female agents (denoted as $\varepsilon_{\mathrm{m}}$ and $\varepsilon_{\mathrm{f}}$, respectively). Additionally, one assumes that those values follow a bivariate normal distribution with a zero mean, unit variance, and correlation $\rho$. Second, the difference in utility that an agent obtains from working versus not working when the partner works differs on the analogous difference in the case that the partner does not work only by a constant term. Those assumptions provide the basis for discrete choice with multiple agents, but to explicitly consider interdependencies, Bjorn and Vuong $(1984,1985)$ and Kooreman (1994) interpret endogenous observed variables as the outcome of a static discrete game. Next, we schematically outline the main conceptual aspect advanced by those authors, mostly following the notation of the latter. The basic steps for identifying different models are as follows: 
i) Parameterize utility levels $U\left(y_{m}, y_{f}\right)$ for the different combinations of discrete choices of the couple in terms of the labour market. The decomposition posed by the random utility model is implemented with a linear functional form for the deterministic component that depends on a vector of exogenous variables. As mentioned before, the latent variable that induces the observed discrete choice consists of differences of utilities levels, and specific differences display discrepancies among themselves by constant terms. Such an assumption greatly reduces the number of possible utility rankings per player. The specifications are summarized as follows:

$$
\begin{array}{ll}
U^{m}(1,1)=x^{\prime} \beta_{1}^{m}+\alpha_{1}^{m}+\varepsilon_{1}^{m} & U^{f}(1,1)=x^{\prime} \beta_{1}^{f}+\alpha_{1}^{f}+\varepsilon_{1}^{f} \\
U^{m}(1,0)=x^{\prime} \beta_{1}^{m}+\varepsilon_{1}^{m} & U^{f}(1,0)=x^{\prime} \beta_{0}^{m}+\alpha_{0}^{f}+\varepsilon_{0}^{m} \\
U^{m}(0,1)=x^{\prime} \beta_{0}^{m}+\alpha_{0}^{m}+\varepsilon_{0}^{m} & U^{f}(0,1)=x^{\prime} \beta_{1}^{f}+\varepsilon_{1}^{f} \\
U^{m}(0,0)=x^{\prime} \beta_{0}^{m}+\varepsilon_{0}^{m} & U^{f}(0,0)=x^{\prime} \beta_{0}^{f}+\varepsilon_{0}^{f}
\end{array}
$$

The contrast between the different formulations [Nash, Stackelberg leadership (by male or female) and imposed Pareto optimality] will emerge in terms of partner-specific constants or differences in the constants identified in each case. It will be convenient to define $\alpha^{i}=\alpha_{1}^{i}-\alpha_{0}^{i}$ and $\varepsilon^{i}=\varepsilon_{1}^{i}-\varepsilon_{0}^{i}$ for $\mathrm{i}=\mathrm{m}$, f.

ii) The different solution concepts will impose restrictions in terms of consistency as related to the best responses of the players. Thus, it will be possible to construct the maximum likelihood functions once probability statements are established for different ranges of the stochastic terms $\varepsilon^{i}$. The relevant details appear in Bjorn and Vuong (1984, 1985) and Kooreman (1994). Next, we sketch some basic aspects in each of the considered models and closely follow, in a more synthetic form, the presentation by Kooreman (1994). ${ }^{3}$

\footnotetext{
${ }^{3}$ The equilibria for the possible configurations in the case of the three solution concepts are detailed in Tables Al, All and All presented in Kooreman (1994).
} 
Nash

The standard Nash equilibrium definition posits a strategy profile (henceforth referred to as an allocation) defined by a pair of discrete choices in the present where no player has a unilateral incentive to deviate or equivalently the equilibrium choices are mutually a best-response to each other. Thus, for Nash equilibrium to prevail, under a strict definition

$$
U^{m}(k, l)>U^{m}(1-k, l) \text { and } U^{f}(k, l)>U^{f}(k, 1-l) \text { for } \mathrm{k}, \mathrm{l}=0,1
$$

Once more, it becomes clear that one must essentially be concerned with the signs of differences in utility levels. Specifically, if we consider the parameterization suggested in (1), the differences $U^{m}(1,1)-U^{m}(0,1), U^{m}(1,0)-U^{m}(0,0), U^{f}(1,1)-U^{f}(1,0)$ and $\mathrm{U}^{f}(0,1)-\mathrm{U}^{f}(0,0)$ will be readily obtained. Furthermore, it becomes clear that $\alpha^{i^{m}}$ and $\alpha_{0}^{i f}$ are not identified in this model.

Finally, a difficulty observed in this model pertains to cases of multiple equilibria or nonexistence of equilibrium. In those cases, Bjorn and Vuong (1984), Kooreman (1994) and Abbott (2009) attributed equal weights for each of the individual outcomes while constructing the maximum likelihood function.

\section{Stackelberg}

Bjorn and Vuong (1985) outline the discrete game formulation in the Stackelberg model. The underlying logic of the model is to introduce an asymmetry between the partners where the leader has the advantage in anticipating his/her partner's best response and incorporating it into its maximization problem. A male leadership model, for example, could be appealing if cultural aspects restrict the autonomy of female participation in decisions. Thus, the consideration of the analysis 
segmented in terms of rural and urban areas will be potentially informative in the case of Brazil as considered in the later application.

An allocation $(k, l)$, for $k, l=0,1$, constitutes a Stackelberg solution with the male as leader and the female as follower if:

$$
U^{f}(k, l)>U^{f}(k, 1-l)
$$

and $\quad U^{m}(k, l)>U^{m}(1-k, l)$

$$
U^{f}(1-k, l)>U^{f}(1-k, 1-l)
$$

or

$$
U^{f}(k, l)>U^{f}(k, 1-l)
$$$$
\text { and } \quad U^{m}(k, l)>U^{m}(1-k, 1-l)
$$

$$
U^{f}(1-k, l)<U^{f}(1-k, 1-l)
$$

In the case that the leadership is reversed, one can readily obtain analogous conditions by switching subscripts. Given the parameterizations that are assumed for the utility levels in expression (1), it is possible to establish the relevant probability statements to construct the maximum likelihood function. The reader is once more referred to the details provided in Bjorn and Vuong (1984, 1985), Kooreman (1994) and Abbott (2009). In this model, it is possible to verify that in the case of male leadership, $\alpha_{1}^{n}, \alpha_{0}^{m}$ and $\alpha^{f}$ are readily identified, whereas $\alpha^{m}$ can be recovered upon the first two parameters. In the case of female leadership, the reverse situation occurs, with the $\alpha_{1}^{f}, \alpha_{0}^{f}$ and $\alpha^{m}$ coefficients being readily identified.

\section{Pareto-Nash}


It is well known that allocations associated with Nash equilibrium need not be Pareto efficient. Kooreman (1994) extended the approach advanced by Bjorn and Vuong $(1984,1985)$ by considering the possibility of imposing Pareto optimality. Thus, it is possible to obtain a closer perspective on a cooperative approach associated with a unitary household. One cannot observe allocations upon which both partners simultaneously improve, and therefore an allocation $(k, l)$ is Pareto efficient if, for $k, l=0,1$ :

$$
\begin{gathered}
U^{m}(k, l)>U^{m}(k, 1-l) \text { or } U^{f}(k, l)>U^{f}(k, 1-l) \\
\text { and } \\
U^{m}(k, l)>U^{m}(1-k, l) \text { or } U^{f}(k, l)>U^{f}(1-k, l) \\
\text { and } \\
U^{m}(k, l)>U^{m}(1-k, 1-l) \text { or } U^{f}(k, l)>U^{f}(1-k, 1-l)
\end{gathered}
$$

However, a shortcoming of the simple imposition of Pareto optimality involves the large number of multiple solutions. Thus, to reduce the number of Pareto optimal solutions, Kooreman (1994) considers the following simplifying assumptions to consider the endogenous variables as outcomes of a mixed Pareto optimality/Nash model:

1) Unique Nash equilibrium

a) If the Nash equilibrium is also Pareto optimal, it is assumed to be the observed outcome.

b) If the Nash equilibrium is not Pareto optimal, there exists exactly one outcome where both the male and the female are better off when compared to the Nash equilibrium; then it is assumed that the players choose such a Pareto efficient allocation.

2) Two Nash equilibria (at least one of these will be Pareto optimal)

a) If only one is Pareto optimal, this is assumed to be the observed outcome.

b) If both Nash equilibria are Pareto optimal, the players are assumed to choose 
one of them with equal probability.

3) No Nash equilibrium and the game involves two, three or four Pareto

optimal allocations. The players are assumed to randomly select one of these

Pareto optimal allocations with equal probabilities.

Notice that difficulties associated with non-existence or multiplicity of equilibria are again approached by attributing equal weights in the maximum likelihood function. In the case of this model, the individual gender-specific parameters $\alpha_{1}^{m}, \alpha_{0}^{m}, \alpha_{1}^{f}$ and $\alpha_{0}^{f}$ are identified.

\section{Data Construction}

This study is based on the annual household survey conducted by the Brazilian statistical bureau [Pesquisa Nacional de Amostra por Domicílios-PNADIBGE] for 2013. In this survey, samples of couples were constructed for rural and urban areas. The dependent variables are given by binary variables indicating participation or non-participation in the labour market. In contrast with Kooreman, who considered a full-time participation criterion for men and a flexible part-time criterion for women, we consider a symmetric principle for both. Specifically, ${ }^{4}$

. $y_{m}=1$ if the man works at least 40 hours per week and 0 otherwise

. $y_{f}=1$ if the woman works at least 40 hours per week and 0 otherwise

In our full sample of 71438 households, we observe the following allocation: $(0,0): 17906$ cases; $(0,1): 4221$ cases; $(1,0): 30125$ cases; and $(1,1): 19186$ cases.

\section{INSERT TABLE 1 AROUND HERE}

\footnotetext{
${ }^{4}$ The econometric analysis also considered regional dummies for the macro regions in Brazil (North, Midwest, Northeast, Southeast and South), and the corresponding estimates can be provided upon request.
} 


\section{Empirical Results}

\section{1- Introduction}

In this section, we discuss the most prominent results and contrasts observed in the different models in comparison with previous analogous evidence for developed economies. All estimations were implemented with Stata codes available in Abbott (2009) using the software Stata 13. First, we will consider the results for rural areas as reported in Table 2.

A first general remark that applies to both rural and urban areas involves the prevalence of non-linear effects for some variables, the similarity of coefficients of some variables across models and gender asymmetries. Those general features also prevailed in the case of Kooreman (1994), who studied the Netherlands, a small, developed and more homogeneous country. However, in the present application, there are dissimilarities with the aforementioned previous work. In particular, it is possible to effectively incorporate the education and nonlabour income controls that led to estimation problems in Kooreman's work. Nevertheless, a general convergence problem prevailed when trying to include a quadratic term for wages in the different models, and thus such a specification was disregarded. Next, we introduce results for the rural and urban areas, respectively, in Tables 2 and 3.

\section{2 - Main results}

\section{$\underline{\text { Rural areas }}$}


From a statistical perspective, the models displayed satisfactory results, with a high proportion of individually significant coefficients at the $5 \%$ significance level that typically displayed expected signs. In terms of the overall fit, the models exhibit similarities and, if we take as reference the information criteria based on the log-likelihood, such as the AIC and BIC, the evidence favours the choice of the Stackelberg male leader model. However, a criterion based on the proportion of correct predictions would favour the Pareto-Nash specification. It is worth mentioning that:

i) The own wage effects are positive in both equations in all models;

ii) The effect of the partner's wage is not symmetric across genders, as WAGEF does appear to have a positive effect on male participation (except for the mixed Pareto-Nash model), whereas WAGEM appears to have an inhibiting effect on female participation under the Nash and Stackelberg female leader models;

iii) Age exerts non-linear effects in both male and female equations, with labour market participation being dampened with the increase of age and with somewhat similar coefficients across the different models;

iv) Education also has non-linear impacts on labour market participation. However, educational levels for men in rural areas do not alter their propensity to work. In the case of the female partner, the result is more clear cut, with a positive effect that slows down with additional years of schooling; ${ }^{5}$

\footnotetext{
${ }^{5}$ Such a consideration is especially discussed in the literature on returns for education, but a limitation of the usually available data refers to the lack of information on education quality. Resende and Wyllie (2006) provide evidence on the positive role of education quality on the aforementioned returns.
} 
v) The number of persons in the household (NPH) appears to display some asymmetry across the male and female equations. The effects are mostly positive and significant in the case of the male equation (with the exception of the Stackelberg female leader specification). In contrast, $\mathrm{NPH}$ appeared to have a negligible role on female labour market participation (again with the exception of the previously mentioned model);

vi) The expected negative effect of non-labour income (NLINC) prevails in the majority of models (with the exception of the Nash and Stackelberg male leader models for females). This also involves the contrasting response to incentives noticed for older men; ${ }^{6}$

vii) The number of children under the age of six (CHILD) can potentially motivate an asymmetry between the two partners in terms of labour market participation. However, the evidence supporting significant negative effects occurs in both genders and under nearly all models. Our variable of interest, the number of children younger than six years old, showed negative parameters for all equations, albeit the effect was much stronger for women, as expected. However, if the sample is restricted to men younger than 55 years old, the parameter loses its statistical significance, while it does not for women; ${ }^{7}$

\footnotetext{
${ }^{6}$ Remarkably, in many smaller municipalities in Brazil, social security and pension benefits are often responsible for sustaining the household. Moreover, in $71.8 \%$ of the municipalities, those benefits surpassed the fiscal transfers from the federal government [see Ministério da Previdência Social (2014)].

7 Unfortunately, the survey data do not include information on daycare availability, but in any case it well known that daycare is much less widespread in rural areas in Brazil. Evidence, as suggested by Gathman and Sass (2012), appears to indicate a non-negligible role of childcare availability on labour supply in terms of the impact of related taxes.
} 
viii) Finally, it is worth commenting on gender-specific parameters or the difference of parameters that are specifically identified under the different models. The $\alpha^{m}$ and $\alpha^{f}$ coefficients show non-negligible variation across the different models and, similar to Kooreman (1994), the former coefficient is negative, whereas the latter is positive. Thus, it is also possible to interpret those coefficients as indicating that, ceteris paribus, the male partner is less likely to participate in the labour market if his female partner works, whereas the male partner's participation tends to positively affect female participation.

\section{$\underline{\text { Urban areas }}$}

Additionally, one mostly observes a satisfactory statistical fit in terms of the individual significance of coefficients and expected signs. The overall fit as indicated by information criteria now favours the Pareto optimality imposed model, whereas the proportion of correct predictions suggests the Stackelberg male leader model as the preferential model.

\section{INSERT TABLE 3 AROUND HERE}

Some specific comments:

i) The own wage coefficients are now always positive and significant for both equations and with similar patterns across models;

ii) Cross wage effects are not significant for male participation (except for a positive influence of WAGEF in the mixed Pareto-Nash model), whereas WAGEM appears to inhibit female participation under all models; 
iii) Non-linear impacts of age prevail with similar patterns across models and decreasing importance of additional years in explaining labour market participation;

iv) The clear non-linear effect of education is similar across models and reveals a decreasing role of additional schooling years on labour force participation;

v) The number of persons in the household (NPH) again has an asymmetric pattern across partners in terms of a positive effect on the man's participation decision but a negligible effect on the woman's participation decision;

vi) Non-labour income (NLINC) negatively affects market participation for both partners, with similar coefficients across models for a given partner;

vii) The number of children below the age of six (CHILD) inhibits labour market participation for both partners, with similar coefficients across models for a given partner;

viii) Once more, the results suggest the same asymmetric patterns that were detected in the rural areas.

\section{3 - Summary of the evidence and preliminary conclusions}

Taking as a reference the previous comments on the results, it is possible to summarize the main observed contrasts between rural and urban areas and between genders. 
The roles of own and cross wages and age in explaining labour market participation are qualitatively similar to the previous evidence provided by Kooreman (1994) for a small developed country.

An important contrast with the previous evidence involves the relevant and robust roles exhibited by education and non-labour income (NLINC) in explaining labour market participation. Thus, the present paper identifies an important inhibiting role on participation accruing from non-labour income.

Educational levels exerted positive influence on the labour participation decision of both members of the family, but not for men in rural areas, whose propensity to work was unaltered despite years of schooling. The coefficient sizes for schooling were substantially higher in urban areas. ${ }^{9}$

Some features of the households also indicate important gender contrasts. The number of persons in the household is significant for male partners only and tends to increase the propensity to participate in the labour market. However, the number of children younger than six years old showed negative parameters for all equations, albeit the effect was much stronger for women, as expected. However, when the sample is restricted to men younger than 55 years old, the parameter loses its statistical significance.

\footnotetext{
${ }^{8}$ However, one has to be cautious about direct comparisons, as Kooreman (1994) adopted a parttime participation criterion for the female partner, and the present study considers a more recent period.

9 Educational levels of the partners may be positively correlated in terms of an assortative mating phenomenon as investigated by Greenwood et al. (2014). We carried out an exploratory estimation that appears to suggest the relevance of that effect. However, female labour market participation is still low in Brazil despite relevant increases over time. In fact, a counterfactual exercise for Brazil involving a random matching procedure indicated a sharp contrast against evidence for the US, where the effect of female labour participation in labour income inequality seems to be substantial, which can be explained by the higher female labor participation rate in the US. It is also important to note that despite the historical increase in female participation in Brazil, as documented by Scorzafave and Menezes-Filho (2001), it remains somewhat low.
} 


\section{Final Comments}

This paper investigated labour force participation by considering a gametheoretic framework where the observed endogenous variables are assumed to be the outcome of a game in accordance to different solution concepts. The consideration of a large and heterogeneous developing economy segmented into rural and urban areas led to statistically sound estimates that partially corroborated previous evidence for a developed country but displayed important contrasts. In fact, the effects pertaining to own wage, cross wage and age effects were qualitatively similar as was the stronger inhibiting role of the number of small children in the case of the female partner.

However, other important asymmetries emerged as given by the more limited role of schooling in labour market participation in rural areas. The very high returns to education in Brazil might shed some light on this question, as urban households have a markedly higher educational level. Important gender contrasts are suggestive in terms of the number of persons in the household. ${ }^{10}$ This variable has a significant effect for male partners only and indicates a larger propensity to participate in the labour market. Although some coefficients are sometimes similar across models, it is possible to observe regional and gender-specific contrasts that reinforce the potential interest in a complex developing economy similar to Brazil. Moreover, the identification of the Stackelberg male leader model as a preferential specification under a particular criterion might indicate that the well-known low

\footnotetext{
${ }^{10}$ There are studies that assess the returns to schooling in Brazil from a regional perspective, such as Suliano and Siqueira (2012), although they do not consider the rural/urban contrast. A summary of the earlier literature on returns to schooling in Brazil appears in Resende and Wyllie (2006).
} 
labour market participation for women in Brazil embodies to some extent a cultural component. It is worth noticing that labour market participation by women can have relevant implications for labour income inequality [see Hoffmann and Leone (2004) and Greenwood et al. (2014)].

The topic of the present paper warrants further investigations, as a large and complex emerging economy similar to Brazil may be more prone to genderspecific issues than more developed economies. In particular, it is possible to suggest at least two avenues for future research:

a) Consider a similar study in a more distant past period; in that case, cultural aspects could have been more relevant and the comparison of the results and evidence of possible contrasts relative to 2013 could be relevant;

b) The maximum likelihood procedures adopted for the estimation of the models relied on random selection when non-existence or multiplicity of equilibria was an issue, with the imposition of equal weights as done in Bjorn and Vuong (1984), Kooreman (1994) and Abbott (2009). A less restrictive treatment of the multiple equilibria phenomenon considered in a recent study would be a pertinent extension [see De Paula (2013) for an overview] 


\section{References}

Abbott, M.R. (2009), Modelling decisions to volunteer at a household level, B.S. honors monograph, University of New South Wales- School of Economics

Barros, R., Ramos, L. Santos, E. (1995), Gender differences in Brazilian labor markets., In P. Schultz (ed.), Investment in Women's Human Capital, Chicago: University of Chicago Press, 380-427 Becker, G. S. (1964), Human Capital, New York: Columbia University Press Bjorn, P.A., Vuong, Q.H. (1984), Simultaneous equations models for dummy endogenous variables: a game theoretic formulation with an application to labor force participation, Social Science Working Paper 537, California Institute of Technology

Bjorn, P.A., Vuong, Q.H. (1985), Econometric modeling of a Stackelberg game with an application to labor force participation, Social Science Working Paper 577, California Institute of Technology

Chiappori, P.A., Donni, O. (2011), Non-unitary models of household behavior: a survey of the literature, In A. Molina (ed.), Household Economic Behaviors, New York: Springer, 1-40

De Paula, A. (2013), Econometric analysis of games with multiple equilibria, Annual Review of Economics, 5, 107-131

Gathman, C., Sass, B. (2012), Taxing childcare: effects on family labor supply and children, IZA DP No. 6440

Greenwood, J., Guner, N., Kocharkov, G., Santos, C. (2014), Marry your like: assortative mating and income inequality, American Economic Review: Papers and Proceedings, $1-10$ 
Grossbard, S. (2011), Independent individual decision-makers in household models and the new home economics, In A. Molina (ed.), Household Economic Behaviors, New York: Springer, 41-56

Heckman, J.J. (1978), Dummy endogenous variables in a simultaneous equation system, Econometrica, 46, 931-960

Hoffmann. R., Leone, E.T. (2004), Participação da mulher no mercado de trabalho e desigualdade da renda domiciliar per capita no Brasil: 1981-2002, Nova Economia, 14, 35-58

Kooreman, P. (1994), Estimation of econometric models of some discrete games, Journal of Applied Econometrics, 9, 255-268

Kooreman, P., Kapteyn, A. (1990), On the empirical implementation of some game theoretic models of household labor supply, Journal of Human Resources, 25, $584-598$

McElroy, M.B. (1990), The empirical content of Nash-bargained household behavior, Journal of Human Resources, 25, 559-83

McFadden, D. (1981), Econometric models of probabilistic choice, In C. Manski and D. McFadden (eds.), Structural Analysis of Discrete Data with Econometric Applications, Cambridge: MIT Press, 198-272

Ministério da Previdência Social (2014), Previdência movimenta economia de municípios brasileiros, http://www.brasil.gov.br/economia-eemprego/2014/01/previdencia-movimenta-economia-de-municipios-brasileiros 
Ramos, L., Aguas, M.F.F., Furtado, L.M.S. (2011), Participação feminina na força de trabalho metropolitano: o papel do status socioeconômico das famílias, Economia Aplicada, 15, 595-611

Reiss, P.C. (1996), Empirical models of discrete strategic choices, American Economic Review: Papers and Proceedings, 86, 421-426

Resende, M., Wyllie, R. (2006), Retornos para educação no Brasil: evidências empíricas adicionais, Economia Aplicada, 10, 349-365

Scorzafave, L.G., Menezes-Filho, N.A. (2001), Participação feminina no mercado de trabalho brasileiro: evolução e determinantes, Pesquisa e Planejamento Econômico, 31, 441-478

Sedlacek, G. L., Santos, E. C. (1991), A mulher cônjuge no mercado de trabalho como estratégia de geração da renda familiar, Pesquisa e Planejamento Econômico, 21, 449-470

Suliano, D.C., Siqueira, M.L. (2012), Retornos da educação no Brasil em âmbito regional considerando um ambiente de menor desigualdade, Economia Aplicada, $16,137-165$

Thomas, D. (1990), Intra-household resource allocation: an inferential approach, Journal of Human Resources, 25, 635-664 
Table 1

Description of variables and summary statistics

\begin{tabular}{|c|c|c|c|c|c|c|c|c|c|}
\hline & & \multicolumn{4}{|c|}{ Rural areas $(n=9157)$} & \multicolumn{4}{|c|}{ Urban areas $(n=61143)$} \\
\hline Variable & Description & Mean & Std.Dev. & Min & Max & Mean & Std. Dev. & Min & $\operatorname{Max}$ \\
\hline AGEM & $\begin{array}{l}\text { Age in years (male } \\
\text { partner) }\end{array}$ & 48.257 & 15.333 & 16 & 101 & 46.237 & 14.589 & 15 & 98 \\
\hline AGEF & $\begin{array}{l}\text { Age in years (female } \\
\text { partner) }\end{array}$ & 44.066 & 14.983 & 13 & 95 & 42.709 & 13.915 & 13 & 90 \\
\hline EDUCM & $\begin{array}{l}\text { Schooling in years } \\
\text { (male partner ) }\end{array}$ & 4.038 & 3.776 & 0 & 17 & 7.960 & 4.583 & 0 & 17 \\
\hline EDUCF & $\begin{array}{l}\text { Schooling in years } \\
\text { (female partner) }\end{array}$ & 5.146 & 4.126 & 0 & 17 & 8.546 & 4.492 & 0 & 17 \\
\hline EMPM & $\begin{array}{l}\text { Employed - } 40 \text { hours } \\
\text { of weekly work } \\
\text { (male partner) }\end{array}$ & 0.640 & 0.480 & 0 & 1 & 0.698 & 0.459 & 0 & 1 \\
\hline EMPF & $\begin{array}{l}\text { Employed - } 40 \text { hours } \\
\text { of weekly work } \\
\text { (female partner) }\end{array}$ & 0.184 & 0.388 & 0 & 1 & 0.345 & 0.476 & 0 & 1 \\
\hline WAGEM & $\begin{array}{l}\text { Monthly wage in } \$ \mathrm{R} \\
\text { (male partner) }\end{array}$ & 717.262 & 941.154 & 0 & 10000 & 1550.014 & 2142.209 & 0 & 50000 \\
\hline WAGEF & $\begin{array}{l}\text { Monthly wage in \$R } \\
\text { (female partner) }\end{array}$ & 185.731 & 433.785 & 0 & 4117 & 641.023 & 1082.269 & 0 & 15000 \\
\hline $\mathrm{NPH}$ & $\begin{array}{l}\text { Number of people } \\
\text { living in household }\end{array}$ & 3.620 & 1.500 & 2 & 14 & 3.542 & 1.365 & 2 & 19 \\
\hline CHILD & $\begin{array}{l}\text { Number of children } \\
\text { younger than } 6 \\
\text { years old living in } \\
\text { household }\end{array}$ & 0.322 & 0.597 & 0 & 5 & 0.313 & 0.573 & 0 & 7 \\
\hline NLINC & $\begin{array}{l}\text { Other non-labor } \\
\text { incomes in \$R }\end{array}$ & 536.024 & 786.767 & 0 & 20100 & 531.218 & 1237.034 & 0 & 27000 \\
\hline
\end{tabular}




\section{Table 2}

Estimation results for rural areas in 2013 (no. of observations: 9157)

\begin{tabular}{|c|c|c|c|c|}
\hline & Nash & $\begin{array}{l}\text { Stackelberg } \\
\text { male leader }\end{array}$ & $\begin{array}{l}\text { Stackelberg } \\
\text { female } \\
\text { leader }\end{array}$ & $\begin{array}{c}\text { Mixed Pareto- } \\
\text { Nash }\end{array}$ \\
\hline$\beta^{m}$ & & & & \\
\hline Constant & $\begin{array}{c}-0.056 \\
(0.739)\end{array}$ & $\begin{array}{c}-0.093 \\
(0.588)\end{array}$ & $\begin{array}{c}-0.142 \\
(0.413)\end{array}$ & $\begin{array}{l}-0.105 \\
(0.546)\end{array}$ \\
\hline WAGEM & $\begin{array}{c}6 \mathrm{E}-04 \\
(0.000)\end{array}$ & $\begin{array}{c}7 E-04 \\
(0.000)\end{array}$ & $\begin{array}{c}-5,7 \mathrm{E}-06 \\
(0.005)\end{array}$ & $\begin{array}{c}7 E-04 \\
(0.000)\end{array}$ \\
\hline WAGEF & $\begin{array}{c}4.2 \mathrm{E}-04 \\
(0.000)\end{array}$ & $\begin{array}{c}2.7 \mathrm{E}-04 \\
(0.020)\end{array}$ & $\begin{array}{c}0.002 \\
(0.000)\end{array}$ & $\begin{array}{l}1.4 \mathrm{E}-04 \\
(0.294)\end{array}$ \\
\hline AGEM & $\begin{array}{c}0.040 \\
(0.000)\end{array}$ & $\begin{array}{c}0.040 \\
(0.000)\end{array}$ & $\begin{array}{c}0.037 \\
(0.000)\end{array}$ & $\begin{array}{c}0.039 \\
(0.000)\end{array}$ \\
\hline $\mathrm{AGEM}^{2}$ & $\begin{array}{l}-6 \mathrm{E}-04 \\
(0.000)\end{array}$ & $\begin{array}{l}-6 \mathrm{E}-04 \\
(0.000)\end{array}$ & $\begin{array}{c}-0.001 \\
(0.000)\end{array}$ & $\begin{array}{l}-6 \mathrm{E}-04 \\
(0.000)\end{array}$ \\
\hline EDUCM & $\begin{array}{c}0.022 \\
(0.063)\end{array}$ & $\begin{array}{c}0.022 \\
(0.066)\end{array}$ & $\begin{array}{c}0.022 \\
(0.080)\end{array}$ & $\begin{array}{c}0.022 \\
(0.064)\end{array}$ \\
\hline EDUCM $^{2}$ & $\begin{array}{c}-0.003 \\
(0.000)\end{array}$ & $\begin{array}{c}-0.003 \\
(0.000)\end{array}$ & $\begin{array}{c}-0.004 \\
(0.000)\end{array}$ & $\begin{array}{c}-0.004 \\
(0.000)\end{array}$ \\
\hline CHILD & $\begin{array}{c}-0.090 \\
(0.003)\end{array}$ & $\begin{array}{c}-0.079 \\
(0,010)\end{array}$ & $\begin{array}{l}-0.048 \\
(0.121)\end{array}$ & $\begin{array}{c}-0.073 \\
(0.020)\end{array}$ \\
\hline $\mathrm{NPH}$ & $\begin{array}{c}0.037 \\
(0.001)\end{array}$ & $\begin{array}{c}0.036 \\
(0.001)\end{array}$ & $\begin{array}{c}0.029 \\
(0.010)\end{array}$ & $\begin{array}{c}0.035 \\
(0.002)\end{array}$ \\
\hline NLINC & $\begin{array}{c}-3.1 \mathrm{E}-04 \\
(0.000)\end{array}$ & $\begin{array}{c}-3.2 \mathrm{E}-04 \\
(0.000)\end{array}$ & $\begin{array}{l}-3 E-04 \\
(0.000)\end{array}$ & $\begin{array}{c}-3.2 \mathrm{E}-04 \\
(0.000)\end{array}$ \\
\hline \multicolumn{5}{|l|}{$\beta^{f}$} \\
\hline Constant & $\begin{array}{l}-2.899 \\
(0.000)\end{array}$ & $\begin{array}{l}-2.561 \\
(0.000)\end{array}$ & $\begin{array}{l}-2.393 \\
(0.000)\end{array}$ & $\begin{array}{l}-2.577 \\
(0.000)\end{array}$ \\
\hline WAGEF & $\begin{array}{c}0.002 \\
(0.000)\end{array}$ & $\begin{array}{c}0.002 \\
(0.000)\end{array}$ & $\begin{array}{c}-2.5 \mathrm{E}-04 \\
(0.000)\end{array}$ & $\begin{array}{c}0.002 \\
(0.000)\end{array}$ \\
\hline WAGEM & $\begin{array}{c}-9.96 \mathrm{E}-05 \\
(0.005)\end{array}$ & $\begin{array}{c}-4.5 \mathrm{E}-05 \\
(0.075)\end{array}$ & $\begin{array}{l}1.8 \mathrm{E}-04 \\
(0.000)\end{array}$ & $\begin{array}{c}-2.5 \mathrm{E}-05 \\
(0.362)\end{array}$ \\
\hline AGEF & $\begin{array}{c}0.048 \\
(0.000)\end{array}$ & $\begin{array}{c}0.048 \\
(0.000)\end{array}$ & $\begin{array}{c}0.050 \\
(0.000)\end{array}$ & $\begin{array}{c}0.050 \\
(0.000)\end{array}$ \\
\hline $\mathrm{AGEF}^{2}$ & $\begin{array}{c}-0.001 \\
(0.000)\end{array}$ & $\begin{array}{c}-0.001 \\
(0.000)\end{array}$ & $\begin{array}{l}-7 E-04 \\
(0.000)\end{array}$ & $\begin{array}{l}-0.001 \\
(0.000)\end{array}$ \\
\hline EDUCF & $\begin{array}{c}0.051 \\
(0.001)\end{array}$ & $\begin{array}{c}0.050 \\
(0.001)\end{array}$ & $\begin{array}{c}0.055 \\
(0.000)\end{array}$ & $\begin{array}{c}0.051 \\
(0.001)\end{array}$ \\
\hline EDUCF $^{2}$ & $\begin{array}{c}-0.005 \\
(0.000)\end{array}$ & $\begin{array}{c}-0.005 \\
(0.000)\end{array}$ & $\begin{array}{l}-0.005 \\
(0.000)\end{array}$ & $\begin{array}{c}-0.005 \\
(0.000)\end{array}$ \\
\hline CHILD & $\begin{array}{l}-0.171 \\
(0.000)\end{array}$ & $\begin{array}{c}-0.168 \\
(0.000)\end{array}$ & $\begin{array}{c}-0.1810 \\
(0.000)\end{array}$ & $\begin{array}{c}-0.172 \\
(0.000)\end{array}$ \\
\hline $\mathrm{NPH}$ & $\begin{array}{c}0.022 \\
(0.161)\end{array}$ & $\begin{array}{c}0.022 \\
(0.132)\end{array}$ & $\begin{array}{c}0.020 \\
(0.177)\end{array}$ & $\begin{array}{c}0.021 \\
(0.142)\end{array}$ \\
\hline NLINC & $\begin{array}{c}-3.3 \mathrm{E}-05 \\
(0.354)\end{array}$ & $\begin{array}{l}-1 E-04 \\
(0.057)\end{array}$ & $\begin{array}{l}-3 \mathrm{E}-04 \\
(0.066)\end{array}$ & $\begin{array}{l}-1 \mathrm{E}-04 \\
(0.033)\end{array}$ \\
\hline$\alpha_{1}^{m}$ & - & $\begin{array}{c}0.191 \\
(0.478)\end{array}$ & - & $\begin{array}{c}0.858 \\
(0.000)\end{array}$ \\
\hline$\alpha_{0}^{n}$ & - & $\begin{array}{c}1.032 \\
(0.000)\end{array}$ & - & $\begin{array}{c}0.335 \\
(0.007)\end{array}$ \\
\hline
\end{tabular}




\begin{tabular}{|c|c|c|c|c|}
\hline$\alpha_{1}^{f}$ & - & - & $\begin{array}{c}0.834 \\
(0.000)\end{array}$ & $\begin{array}{c}0.378 \\
(0.110)\end{array}$ \\
\hline$\alpha_{0}^{f}$ & - & - & $\begin{array}{c}0.606 \\
(0.002)\end{array}$ & $\begin{array}{c}0.828 \\
(0.000)\end{array}$ \\
\hline$\alpha^{m}$ & $\begin{array}{l}-1.084 \\
(0.000)\end{array}$ & $\begin{array}{l}-0.842^{*} \\
(0.013)\end{array}$ & $\begin{array}{c}0.388 \\
(0.001)\end{array}$ & - \\
\hline$\alpha^{f}$ & $\begin{array}{c}0.869 \\
(0.010)\end{array}$ & $\begin{array}{c}0.489 \\
(0.000)\end{array}$ & $\begin{array}{c}0.228^{\star \star} \\
(0.274)\end{array}$ & - \\
\hline$\rho$ & $\begin{array}{c}0.577 \\
(0.000)\end{array}$ & $\begin{array}{c}0.445 \\
(0.000)\end{array}$ & $\begin{array}{c}0.025 \\
(0.827)\end{array}$ & $\begin{array}{c}0.411 \\
(0.009)\end{array}$ \\
\hline loglikelihood & -7450.9 & -7445.9 & -7450.6 & -7445.9 \\
\hline AIC & 14959.8 & 14951.7 & 14961.2 & 14953.7 \\
\hline $\mathrm{BIC}$ & 15166.3 & 15165.4 & 15174.9 & 15174.5 \\
\hline $\begin{array}{l}\% \text { of correct } \\
\text { predictions }\end{array}$ & 0.808 & 0.803 & 0.809 & 0.814 \\
\hline
\end{tabular}

Note: $\mathrm{p}$-values are reported in parentheses; ( ${ }^{*}$ ) obtained upon the $\alpha_{1}^{n}$ and $\alpha_{0}^{m}$ estimated coefficients; $\left(^{* *}\right)$ obtained upon the $\alpha_{1}^{f}$ and $\alpha_{0}^{f}$ estimated coefficients 


\section{Table 3}

Estimation results for urban areas in 2013 (no. of observations: 61143)

\begin{tabular}{|c|c|c|c|c|}
\hline & Nash & $\begin{array}{l}\text { Stackelberg } \\
\text { male leader }\end{array}$ & $\begin{array}{l}\text { Stackelberg } \\
\text { female } \\
\text { leader }\end{array}$ & Mixed Pareto-Nash \\
\hline \multicolumn{5}{|l|}{$\beta^{m}$} \\
\hline Constant & $\begin{array}{l}-0.200 \\
(0.005) \\
\end{array}$ & $\begin{array}{l}-0.206 \\
(0.004) \\
\end{array}$ & $\begin{array}{l}-0.186 \\
(0.007) \\
\end{array}$ & $\begin{array}{l}-0.049 \\
(0.541) \\
\end{array}$ \\
\hline WAGEM & $\begin{array}{l}2.6 \mathrm{E}-04 \\
(0.000)\end{array}$ & $\begin{array}{c}2.6 \mathrm{E}-04 \\
(0.000) \\
\end{array}$ & $\begin{array}{c}2.6 \mathrm{E}-04 \\
(0.000)\end{array}$ & $\begin{array}{c}2.4 \mathrm{E}-04 \\
(0.000) \\
\end{array}$ \\
\hline WAGEF & $\begin{array}{c}0.000 \\
(0.260)\end{array}$ & $\begin{array}{c}0.000 \\
(0.850)\end{array}$ & $\begin{array}{c}0.000 \\
(0.490)\end{array}$ & $\begin{array}{l}1.4 \mathrm{E}-04 \\
(0,008)\end{array}$ \\
\hline AGEM & $\begin{array}{c}0.059 \\
(0.000) \\
\end{array}$ & $\begin{array}{c}0.059 \\
(0.000) \\
\end{array}$ & $\begin{array}{c}0.060 \\
(0.000) \\
\end{array}$ & $\begin{array}{c}0.058 \\
(0.000) \\
\end{array}$ \\
\hline AGEM $^{2}$ & $\begin{array}{l}-9 E-04 \\
(0.000) \\
\end{array}$ & $\begin{array}{l}-9 \mathrm{E}-04 \\
(0.000) \\
\end{array}$ & $\begin{array}{l}-9 \mathrm{E}-04 \\
(0.000) \\
\end{array}$ & $\begin{array}{l}-9 \mathrm{E}-04 \\
(0.000) \\
\end{array}$ \\
\hline EDUCM & $\begin{array}{c}0.059 \\
(0.000)\end{array}$ & $\begin{array}{c}0.056 \\
(0.000)\end{array}$ & $\begin{array}{c}0.056 \\
(0.000)\end{array}$ & $\begin{array}{c}0.060 \\
(0.000)\end{array}$ \\
\hline EDUCM $^{2}$ & $\begin{array}{l}-0.004 \\
(0.000) \\
\end{array}$ & $\begin{array}{l}-0.004 \\
(0.000) \\
\end{array}$ & $\begin{array}{l}-0.004 \\
(0.000) \\
\end{array}$ & $\begin{array}{l}-0.005 \\
(0.000) \\
\end{array}$ \\
\hline CHILD & $\begin{array}{l}-0.039 \\
(0.003)\end{array}$ & $\begin{array}{l}-0.038 \\
(0.004)\end{array}$ & $\begin{array}{l}-0.043 \\
(0.001)\end{array}$ & $\begin{array}{l}-0.066 \\
(0.000)\end{array}$ \\
\hline $\mathrm{NPH}$ & $\begin{array}{c}0.024 \\
(0.000) \\
\end{array}$ & $\begin{array}{c}0.024 \\
(0.000) \\
\end{array}$ & $\begin{array}{c}0.024 \\
(0.000) \\
\end{array}$ & $\begin{array}{c}0.024 \\
(0.000) \\
\end{array}$ \\
\hline NLINC & $\begin{array}{l}-2 \mathrm{E}-04 \\
(0.000)\end{array}$ & $\begin{array}{l}-2 \mathrm{E}-04 \\
(0.000)\end{array}$ & $\begin{array}{l}-2 \mathrm{E}-04 \\
(0.000)\end{array}$ & $\begin{array}{l}-2 \mathrm{E}-04 \\
(0.000)\end{array}$ \\
\hline \multicolumn{5}{|l|}{$\beta^{f}$} \\
\hline Constant & $\begin{array}{l}-1.770 \\
(0.000) \\
\end{array}$ & $\begin{array}{l}-1.747 \\
(0.000) \\
\end{array}$ & $\begin{array}{c}-1.762 \\
(0,000) \\
\end{array}$ & $\begin{array}{l}-1.838 \\
(0,000) \\
\end{array}$ \\
\hline WAGEF & $\begin{array}{c}0.001 \\
(0.000) \\
\end{array}$ & $\begin{array}{c}0.001 \\
(0.000) \\
\end{array}$ & $\begin{array}{c}0.001 \\
(0.000) \\
\end{array}$ & $\begin{array}{c}0.001 \\
(0.000) \\
\end{array}$ \\
\hline WAGEM & $\begin{array}{l}-1 \mathrm{E}-04 \\
(0.000)\end{array}$ & $\begin{array}{l}-1 \mathrm{E}-04 \\
(0.000)\end{array}$ & $\begin{array}{l}-1 \mathrm{E}-04 \\
(0.000)\end{array}$ & $\begin{array}{l}-1 \mathrm{E}-04 \\
(0.000)\end{array}$ \\
\hline AGEF & $\begin{array}{c}0.050 \\
(0.000)\end{array}$ & $\begin{array}{c}0.050 \\
(0.000)\end{array}$ & $\begin{array}{c}0.050 \\
(0.000)\end{array}$ & $\begin{array}{c}0.032 \\
(0.000)\end{array}$ \\
\hline $\mathrm{AGEF}^{2}$ & $\begin{array}{l}-0.001 \\
(0.000) \\
\end{array}$ & $\begin{array}{l}-0.001 \\
(0.000) \\
\end{array}$ & $\begin{array}{l}-0.001 \\
(0.000) \\
\end{array}$ & $\begin{array}{l}-4 \mathrm{E}-04 \\
(0.000) \\
\end{array}$ \\
\hline EDUCF & $\begin{array}{c}0.110 \\
(0.000)\end{array}$ & $\begin{array}{c}0.110 \\
(0.000) \\
\end{array}$ & $\begin{array}{c}0.110 \\
(0.000) \\
\end{array}$ & $\begin{array}{c}0.093 \\
(0.000) \\
\end{array}$ \\
\hline EDUCF $^{2}$ & $\begin{array}{l}-0.007 \\
(0.000)\end{array}$ & $\begin{array}{l}-0.007 \\
(0.000)\end{array}$ & $\begin{array}{l}-0.007 \\
(0.000)\end{array}$ & $\begin{array}{l}-0.006 \\
(0.000)\end{array}$ \\
\hline CHILD & $\begin{array}{l}-0.188 \\
(0.000)\end{array}$ & $\begin{array}{l}-0.188 \\
(0.000)\end{array}$ & $\begin{array}{l}-0.188 \\
(0.000)\end{array}$ & $\begin{array}{l}-0.187 \\
(0.000)\end{array}$ \\
\hline $\mathrm{NPH}$ & $\begin{array}{l}-0.009 \\
(0.118)\end{array}$ & $\begin{array}{l}-0.008 \\
(0.130) \\
\end{array}$ & $\begin{array}{l}-0.008 \\
(0.140) \\
\end{array}$ & $\begin{array}{l}-0.005 \\
(0.323) \\
\end{array}$ \\
\hline NLINC & $\begin{array}{l}-1 \mathrm{E}-04 \\
(0.000) \\
\end{array}$ & $\begin{array}{l}-1 \mathrm{E}-04 \\
(0.000) \\
\end{array}$ & $\begin{array}{l}-1 \mathrm{E}-04 \\
(0.000) \\
\end{array}$ & $\begin{array}{l}-1 \mathrm{E}-04 \\
(0.000) \\
\end{array}$ \\
\hline$\alpha_{1}^{m}$ & - & $\begin{array}{l}-0.143 \\
(0.351)\end{array}$ & - & $\begin{array}{c}0.845 \\
(0.000)\end{array}$ \\
\hline$\alpha_{0}^{m}$ & - & $\begin{array}{c}0.044 \\
(0.800)\end{array}$ & - & $\begin{array}{c}0.050 \\
(0,007)\end{array}$ \\
\hline
\end{tabular}




\begin{tabular}{|l|c|c|c|c|}
\hline$\alpha_{1}^{f}$ & - & - & $\begin{array}{c}-0.363 \\
(0.000)\end{array}$ & $\begin{array}{c}2.174 \\
(0.000)\end{array}$ \\
\hline$\alpha_{0}^{f}$ & & & -0.509 & 2.781 \\
& - & - & $(0.000)$ & $(0.000)$ \\
\hline$\alpha^{m}$ & & & -0.223 & - \\
& $(0.005)$ & $(0.014)$ & $(0,000)$ & - \\
\hline$\alpha^{f}$ & 0.187 & 0.152 & $0.146^{* *}$ & $(0.005)$ \\
\hline$\rho$ & $(0.001)$ & $(0.002)$ & 0.336 & 0.496 \\
& 0.231 & 0.221 & $(0.000)$ & -54433.7 \\
\hline loglikelihood & -54466.6 & -54467.3 & -54450.9 & 108933.3 \\
\hline AIC & 108995.3 & 108998.7 & 108965.8 & 109231 \\
\hline BIC & 109274.9 & 109287.3 & 109254.5 & 0.767 \\
\hline $\begin{array}{l}\text { \% of correct } \\
\text { predictions }\end{array}$ & 0.795 & 0.799 & 0.795 & \\
\hline
\end{tabular}

Note: p-values are reported in parentheses; ( ${ }^{*}$ ) obtained upon the $\alpha_{1}^{n}$ and $\alpha_{0}^{m}$ estimated coefficients; $\left.{ }^{* *}\right)$ obtained upon the $\alpha_{1}^{f}$ and $\alpha_{0}^{f}$ estimated coefficients 